\title{
Total phenolic content, cyclooxygenases, a-glucosidase, acetylcholinesterase, tyrosinase inhibitory and DPPH radical scavenging effects of Cornus sanguinea leaves and fruits
}

\author{
Burak BARUT ${ }^{1}$ * (D), Didem ŞÖHRETOĞLU 2 (D) \\ 1 Department of Biochemistry, Faculty of Pharmacy, Karadeniz Technical University, Trabzon, Turkey. \\ 2 Department of Pharmacognosy, Faculty of Pharmacy, Hacettepe University, Ankara, Turkey. \\ * Corresponding Author. E-mail: burak.barut@hotmail.com, burakbarut@ktu.edu.tr (B.B.); Tel. +90-462-377 88 50.
}

Received: 23 June 2020 / Revised: 11 August 2020/ Accepted: 20 August 2020

\begin{abstract}
The aim of the present study was to investigate total phenolic content and biological effects of methanol extracts from Cornus sanguinea L. leaves (LME) and fruits (FME). Total phenolic contents, COX-1/COX-2, aglucosidase, AChE, tyrosinase inhibitory and DPPH radical scavenging effects of both extracts were investigated by using spectrophotometric methods. The total phenolic contents of LME and FME were determined as $191.14 \pm 4.84$ and $31.51 \pm 2.68 \mathrm{mg} \mathrm{GAE} / \mathrm{g}$ dry weight, respectively. LME inhibited COX-1 enzyme $70.71 \pm 1.88 \%$ and $79.38 \pm 0.92 \%$ at 50 and $100 \mu \mathrm{g} / \mathrm{mL}$. LME had higher COX-1 and COX-2 inhibitory effects than that of FME. LME inhibited aglucosidase stronger than positive control, acarbose. On the other hand, both extracts showed lower AChE inhibition actions compared to positive control, galantamine. Moreover, LME had higher tyrosinase inhibitory effect than FME. Both extracts scavenged DPPH radical in a concentration-dependent manner. Also, LME had stronger scavenging effect than that of FME. To our knowledge, current work is the first report on tyrosinase, AChE, as well as COX-1 inhibitory properties of $C$. sanguinea. These results suggested that LME of C. sanguinea have a promising potential for the treatment of several disorders but further studies are needed to support the this assumption.
\end{abstract}

KEYWORDS: Acetylcholinesterase; antioxidant; cyclooxygenase; Cornus sanguinea; a-glucosidase; tyrosinase.

\section{INTRODUCTION}

The species of Cornus have significant biological effects due to the presence of ascorbic acid, phenolic compounds, flavonoids, anthocyanins [1]. Their leaves and fruits have antioxidant, antimicrobial, antiinflammatory, cytoprotective, antidiabetic effects [2]. The genus Cornus is represented by two species in Turkey. Cornus sanguinea L. (Cornaceae), is a small tree with purplish-black drupe fruits [3]. An infusion prepared from C. sanguinea barks is used as an astringent and it is applied topically to sore eyes in Serbia [4]. C. sanguninea fruits are consumed as food and for medicinal purposes in Turkey. They are eaten as jam and also are used the treatment of diarrhea [5,6]. Fruits and leaves of the plant are rich in phenolic compounds [2,7]. Presence of some quercetin derivatives, including quercetin-3-O-glucuronide, quercetin-3-Ogalactoside, quercetin-3-O-glucoside, quercetin-3-O-rhamnoside and quercetin-3-O-rutinoside in fruits determined by LC-MS/MS [8]. An ethanol extract of leaves, flowers and stems (2:1:1) of C. sanguinea inhibited methicillin resistant Staphylococcus aureus and Candida albicans with MIC values of 8 and 12.6 $\mathrm{mg} / \mathrm{ml}[9]$.

Inflammation is a basic defense mechanism against injury or infection and characterized by many symptoms such as redness, heat, pain, and swelling [10]. The main metabolic process in the inflammatory is the arachidonic acid (AA) pathway. In this pathway, the cyclooxygenase (COX) enzymes form prostaglandins which are responsible for the pain and associated with process of inflammation [11]. Its processes are involved in severe degenerative disorders including rheumatoid arthritis, cardiovascular disease, asthma, diabetes, epilepsy, Alzheimer's disease, neurotoxicity etc. [12].

Diabetes mellitus (DM), is one of the degenerative diseases, cause to severe complications such as diabetic nephropathy, neuropathy, and cardiovascular diseases etc. a-Glucosidase enzyme is a key role for the hydrolysis and absorption of carbohydrates [13]. Its inhibitors are used for the treatment of DM since

How to cite this article: Barut $B$, Şöhretoğlu D. Total phenolic content, cyclooxygenases, $\alpha$-glucosidase, acetylcholinesterase, tyrosinase inhibitory and DPPH radical scavenging effects of Cornus sanguinea leaves and fruits. J Res Pharm. 2020; 24(5): 623-631. 
they regulate postprandial blood glucose and insulin levels [14]. In recent years, researchers have been looking for new, natural, and with less side effects a-glucosidase inhibitors against DM due to the gastrointestinal side effects of drugs used in the clinic.

Alzheimer disease $(\mathrm{AD})$ is one of the disorders that cause decreased cognitive functions and memory loss [15]. Acetylcholinesterase ( $\mathrm{AChE}$ ) catalyzes the hydrolysis of the neurotransmitter acetylcholine to choline and acetic acid [16]. Improving cholinergic function by inhibition of AChE is an important method for the symptomatic treatment of $\mathrm{AD}$. Cholinesterase inhibitors increase cholinergic transmission by inhibiting the AChE [17].

Tyrosinase is widely found in plant, animals, fungi and bacteria and catalyzes by oxidizing monophenols to diphenols and diphenols to quinones and finally quinones generate melanine which prevent ultraviolet damage from sunlight on the skin [18]. However, the excessive generation of melanin triggers several disorders such as melanoma, age spots, neurodegenerative disesases etc [19]. In addition, tyrosinase causes degradation of nutritional values due to browning problems for fruits and vegetables [19]. So, tyrosinase inhibitors have been extremely interesting in the cosmetic and pharmaceutical as well as food industry in recent years.

The aim of present study was to investigate total phenolic content and biological effects of methanol extracts from C. sanguinea leaves (LME) and fruits (FME).

\section{RESULTS}

\subsection{Estimation of total phenolic content}

The total phenolic contents of LME and FME were determined as $191.14 \pm 4.84 \mathrm{mg}$ GAE/g dry weight, $31.51 \pm 2.68 \mathrm{mg}$ GAE$/ \mathrm{g}$ dry weight, respectively.

\subsection{COX-1 and COX-2 inhibitory effects of LME and FME}

The in vitro COX-1 and COX-2 inhibitory effects of LME and FME were presented in Figures 1 and 2. The obtained results were expressed as percent of inhibition (\%) and $\mathrm{IC}_{50}$ values. As shown in Figure 1, LME inhibited COX-1 enzyme with $45.31 \pm 1.49 \%, 62.80 \pm 2.53 \%, 70.71 \pm 1.88 \%$ and $79.38 \pm 0.92 \%$ at $12.5,25,50$ and $100 \mu \mathrm{g} / \mathrm{ml}$. It showed significant COX-1 inhibitory effect when compared to diclofenac at 25 and 100 $\mu \mathrm{g} / \mathrm{ml}(\mathrm{p}<0.01)$. In addition, the $\mathrm{IC}_{50}$ value of LME $(13.60 \pm 2.04 \mu \mathrm{g} / \mathrm{ml})$ was lower than diclofenac $(17.55 \pm$ $0.91 \mu \mathrm{g} / \mathrm{ml})$. On the other hand, FME had low inhibitory properties against COX-1. In COX-2 inhibition assay, At $100 \mu \mathrm{g} / \mathrm{ml}$, LME displayed significant inhibition as compared to celecoxib ( $<<0.001)$. The $\mathrm{IC}_{50}$ value of LME was determined as $11.39 \pm 2.39 \mu \mathrm{g} / \mathrm{ml}$ on COX-2.

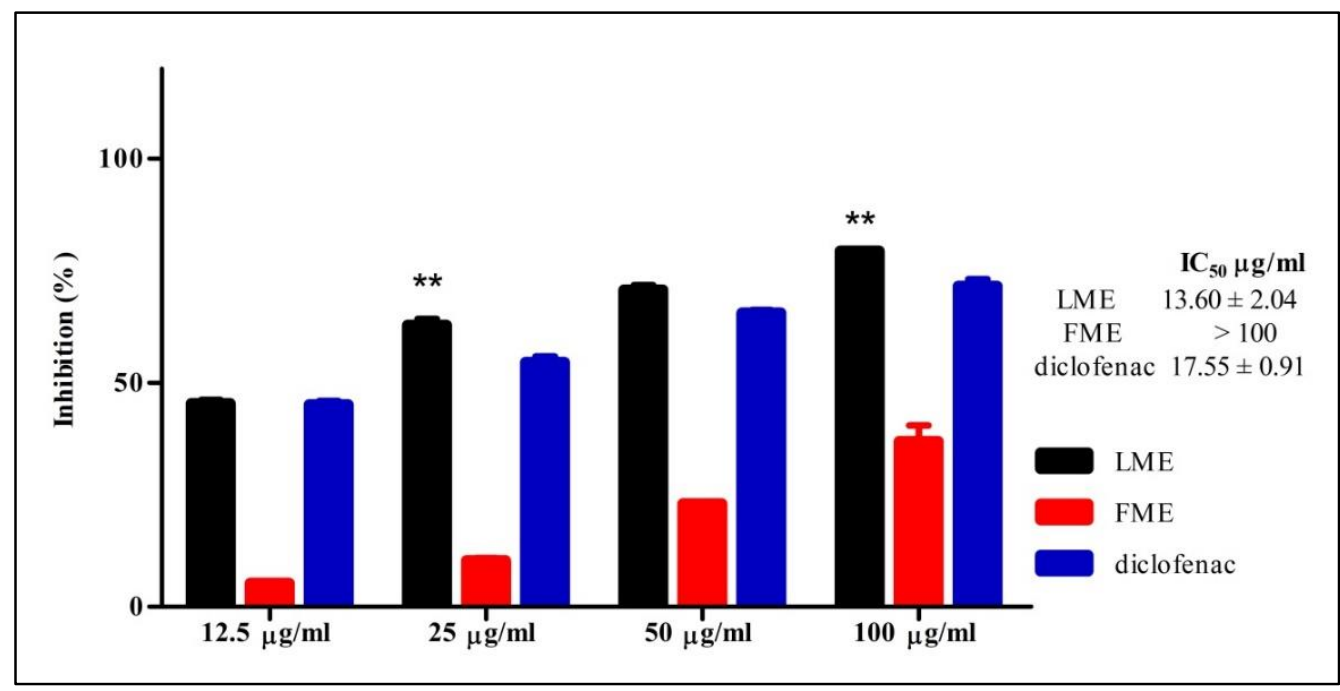

Figure 1. Inhibitory effects (\%) of LME and FME on COX-1. ${ }^{* *} \mathrm{p}<0.01$ comparing positive control at same concentrations. 


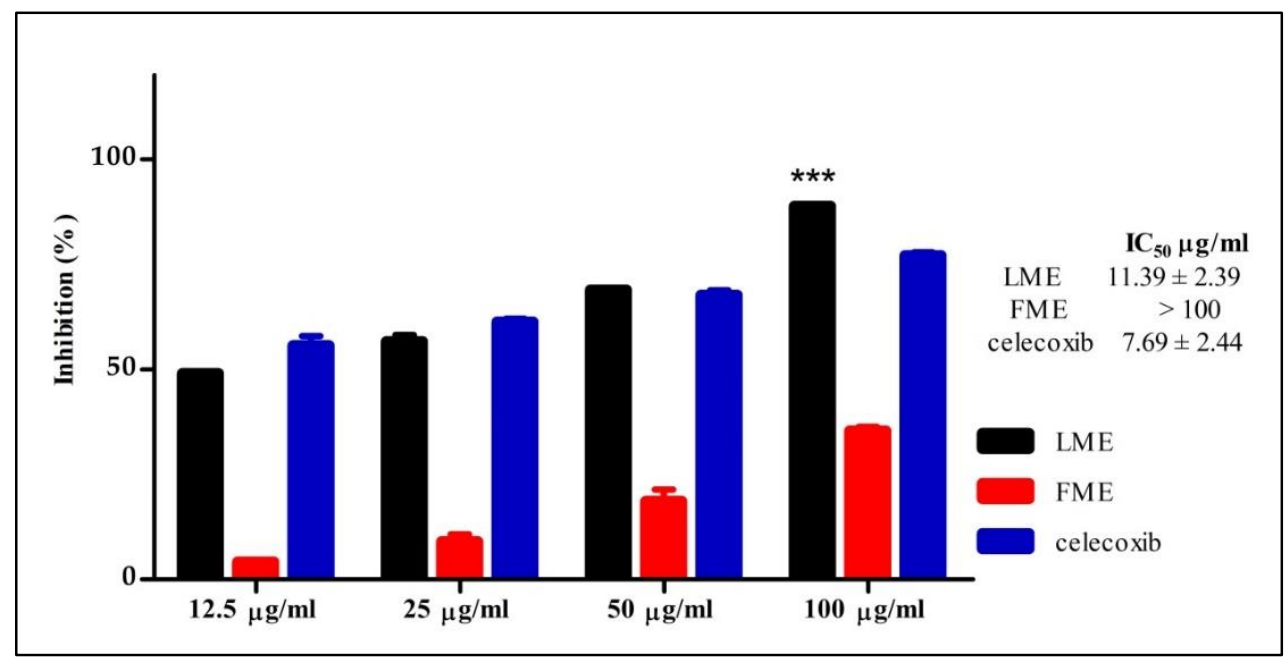

Figure 2. Inhibitory effects (\%) of LME and FME on COX-2. ${ }^{* * *} \mathrm{p}<0.001$ comparing positive control at same concentrations.

\section{3. a-Glucosidase inhibitory effects of LME and FME}

The in vitro a-glucosidase inhibitory properties of the extracts were given in Table 1 . The obtained results were expressed as percent inhibition (\%) and $\mathrm{IC}_{50}$ values. LME inhibited a-glucosidase in a concentration-dependent manner as shown in Table 1. At 25, 50 and $100 \mu \mathrm{g} / \mathrm{ml}, \mathrm{LME}$ had significant inhibition actions when compared to acarbose $(\mathrm{p}<0.001)$. The $\mathrm{IC}_{50}$ value of LME was determined as $19.14 \pm$ $0.21 \mu \mathrm{g} / \mathrm{ml}$. On the other hand, FME did not show any inhibitory action at studied concentrations.

Table 1. Inhibitory effects (\%) of LME and FME on a-glucosidase.

\begin{tabular}{cccccc}
\hline & $\mathbf{1 2 . 5} \boldsymbol{\mu g} / \mathbf{m l}$ & $\mathbf{2 5} \boldsymbol{\mu g} / \mathbf{m l}$ & $\mathbf{5 0} \boldsymbol{\mu g} / \mathbf{m l}$ & $\mathbf{1 0 0} \boldsymbol{\mu g} / \mathbf{m l}$ & $\mathrm{IC}_{\mathbf{5 0}} \boldsymbol{\mu g} / \mathbf{m l}$ \\
\hline LME & $23.57 \pm 4.24$ & $74.81 \pm 5.03^{* * *}$ & $86.09 \pm 0.45^{\star * *}$ & $88.76 \pm 0.06^{* * *}$ & $19.14 \pm 0.21$ \\
FME & nd & nd & nd & nd & nd \\
Acarbose & $20.64 \pm 2.53$ & $39.78 \pm 0.53$ & $47.85 \pm 1.41$ & $62.85 \pm 1.41$ & $51.24 \pm 1.27$ \\
\hline
\end{tabular}

*** $\mathrm{p}<0.001$ comparing positive control at same concentrations. nd: not determined.

\subsection{AChE inhibitory effects of LME and FME}

The in vitro AChE inhibitory potentials of the extracts were given in Table 2 and the obtained results were expressed as percent inhibition (\%) and $\mathrm{IC}_{50}$ values. As given in Table 2, LME showed inhibitory effects on AChE with $16.84 \pm 2.55 \%, 25.54 \pm 1.47 \%, 36.71 \pm 0.55 \%$ and $50.89 \pm 1.49 \%$ at $12.5,25,50$ and $100 \mu \mathrm{g} / \mathrm{ml}$. While FME did not display inhibition on AChE at 12.5 and $25 \mu \mathrm{g} / \mathrm{ml}$, it showed inhibitory effects with 11.59 $\pm 1.51 \%$ and $24.58 \pm 1.49 \%$ at 50 and $100 \mu \mathrm{g} / \mathrm{ml}$. The $\mathrm{IC}_{50}$ values of LME and FME were $93.64 \pm 2.98$ and $>100$ $\mu \mathrm{g} / \mathrm{ml}$, respectively. The results showed that both extracts showed lower inhibitory effects when compared to galantamine which used as a positive control.

Table 2. Inhibitory effects (\%) of LME and FME against AChE.

\begin{tabular}{cccccc}
\hline & $\mathbf{1 2 . 5} \boldsymbol{\mu g} / \mathbf{m l}$ & $\mathbf{2 5} \boldsymbol{\mu g} / \mathbf{m l}$ & $\mathbf{5 0} \boldsymbol{\mu g} / \mathbf{m l}$ & $\mathbf{1 0 0} \boldsymbol{\mu g} / \mathbf{m l}$ & $\mathbf{I C}_{\mathbf{5 0}} \boldsymbol{\mu g} / \mathbf{m l}$ \\
\hline LME & $16.84 \pm 2.55$ & $25.54 \pm 1.47$ & $36.71 \pm 0.55$ & $50.89 \pm 1.49$ & $93.64 \pm 2.98$ \\
FME & nd & nd & $11.59 \pm 1.51$ & $24.58 \pm 1.49$ & $>100$ \\
Galantamine & $76.52 \pm 2.12$ & $85.44 \pm 1.59$ & $90.96 \pm 0.34$ & $92.46 \pm 1.99$ & $<12.50$ \\
\hline
\end{tabular}

nd: not determined 


\subsection{Tyrosinase inhibitory effects of LME and FME}

The in vitro tyrosinase inhibitory effects of the both extracts were presented in Figure 3 and the obtained results were expressed as percent of inhibition (\%) and $\mathrm{IC}_{50}$ values. LME had higher inhibition action than that of FME but kojic acid showed stronger inhibitory effect than both extracts at studied concentrations. At 12.5, 25, 50 and $100 \mu \mathrm{g} / \mathrm{ml}$, both extracts inhibited tyrosinase with $12.97 \pm 0.61 \%, 36.42 \pm$ $0.80 \%, 60.00 \pm 2.51 \%$ and $66.49 \pm 0.38 \%$ for LME and $9.23 \pm 1.72 \%, 23.95 \pm 0.42 \%, 49.50 \pm 2.81 \%$ and $82.49 \pm$ $1.32 \%$ for FME, respectively. The $\mathrm{IC}_{50}$ values of LME and FME were $44.45 \pm 3.31$ and $65.06 \pm 2.41 \mu \mathrm{g} / \mathrm{ml}$, respectively.

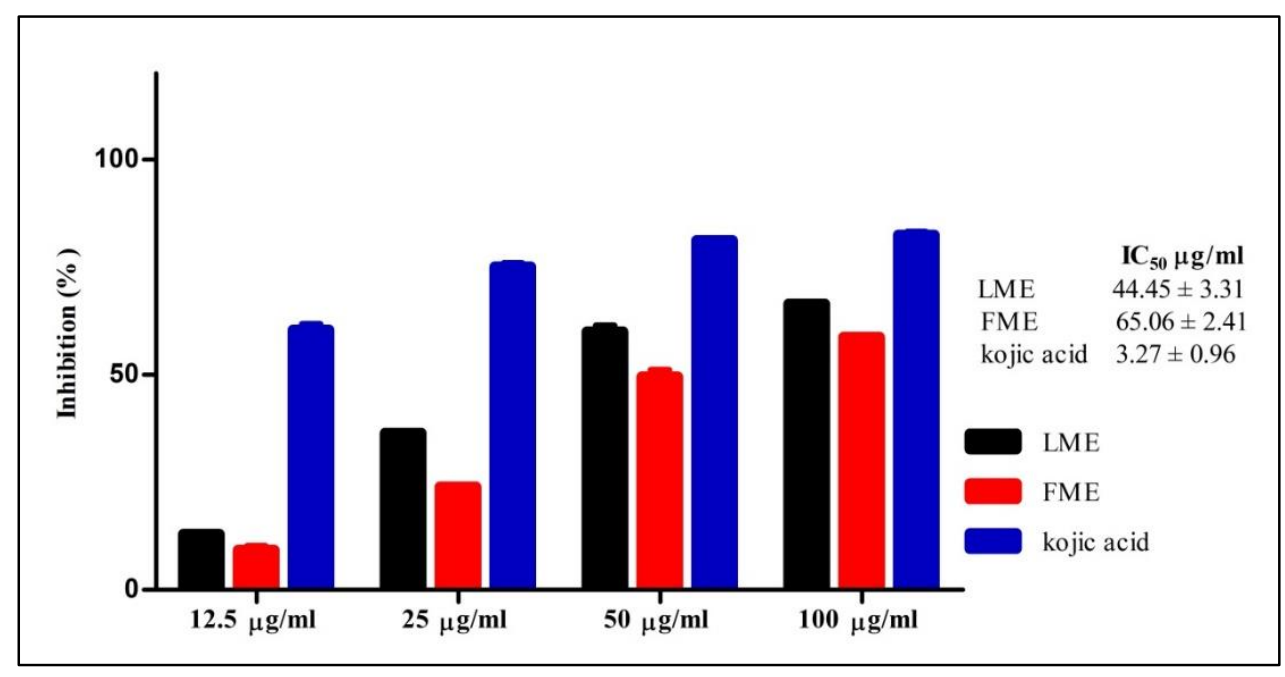

Figure 3. Inhibitory effects (\%) of LME and FME on tyrosinase.

\subsection{DPPH radical scavenging effects of LME and FME}

The DPPH radical scavenging effects of the both extracts were shown in Table 3. The obtained results were expressed as percent of inhibition (\%) and $\mathrm{IC}_{50}$ values. Both extracts scavenged DPPH radical in a concentration-dependent manner as presented in Table 3. At 50 and $100 \mu \mathrm{g} / \mathrm{ml}$, LME had remarkable radical scavenging actions with $75.76 \pm 2.56 \%$ and $92.34 \pm 0.87 \%$, respectively. The $\mathrm{IC}_{50}$ values of $\mathrm{LME}$ was 27.27 $\pm 1.30 \mu \mathrm{g} / \mathrm{ml}$. In addition, LME had stronger scavenging effects that of FME at studied concentrations.

Table 3. DPPH radical scavenging effects (\%) of LME and FME.

\begin{tabular}{cccccc}
\hline & $\mathbf{1 2 . 5} \boldsymbol{\mu \mathrm { g } / \mathrm { ml }}$ & $\mathbf{2 5} \boldsymbol{\mu g} / \mathbf{m l}$ & $\mathbf{5 0} \boldsymbol{\mu g} / \mathbf{m l}$ & $\mathbf{1 0 0} \boldsymbol{\mu g} / \mathbf{m l}$ & $\mathbf{I C}_{\mathbf{5 0}} \boldsymbol{\mu g} / \mathbf{m l}$ \\
\hline LME & $23.52 \pm 0.22$ & $44.14 \pm 3.10$ & $75.76 \pm 2.56$ & $92.34 \pm 0.87$ & $27.27 \pm 1.30$ \\
FME & $3.79 \pm 2.57$ & $8.05 \pm 4.00$ & $16.10 \pm 3.71$ & $29.51 \pm 3.32$ & $>100$ \\
Gallic acid & $89.78 \pm 0.64$ & $91.76 \pm 0.38$ & $92.19 \pm 0.35$ & $92.92 \pm 0.74$ & $<12.50$ \\
\hline
\end{tabular}

\section{DISCUSSION}

Plants and their extracts have been used for treatment of many disorders. Stankovic and Topuzovic reported that the species of the genus Cornus are used in veterinary medicine, pharmacy, and traditional medicine since they have rich in phenolic compounds and show various biological activities such as antioxidant, anti-inflammatory, cytoprotective, and antidiabetic etc. [2]. To the best of our knowledge, tyrosinase, AChE, as weel as COX-1 inhibitory properties of the plant investigated for the first time by current work. In this study, the total phenolic contents of LME and FME were found to be $191.14 \pm 4.84 \mathrm{mg}$ GAE/g dry weight, $31.51 \pm 2.68 \mathrm{mg}$ GAE/g dry weight, respectively. LME had higher total phenolic content than that of FME about six-fold. Stankovic and Topuzovic reported that the total phenolic and flavonoid contents in the methanol extracts of $C$. sanguinea leaves and fruits were determined as $205.74 \pm 0.49 \mathrm{mg}$ GA/g extract and $34.19 \pm 0.25 \mathrm{mg}$ GA/g extract, $23.24 \pm 0.16 \mathrm{mg}$ rutin/g extract, $14.40 \pm 0.09 \mathrm{mg}$ rutin/g extract, respectively [2]. Their results showed that $C$. sanguniea leaves contain more phenolics and flavonoids 
compared to the fruits. Therefore, it is thought that LME showed higher activity than FME for in vitro biological activity studies that we used. In this study, we investigated in vitro COX-1 and COX-2 inhibitory effects of LME and FME by using spectrophotometric method. The obtained results demonstrated that LME had higher COX-1 and COX-2 inhibitory actions than FME and showed significant COX-1 inhibitory effect when compared to diclofenac at 25 and $100 \mu \mathrm{g} / \mathrm{ml}(\mathrm{p}<0.01)$. For COX-2, LME showed significant inhibition as compared to celecoxib at $100 \mu \mathrm{g} / \mathrm{ml}(\mathrm{p}<0.001)$. Popovic et al. reported that methanol extract of $C$. sanguinea fresh fruit were analyzed using LC-MS/MS and determined contents of neochlorogenic acid, quercetin-3-O-glucuronide, quercetin-3-O-galactoside, quercetin-3-O-glucoside, quercetin-3-O-rhamnoside, and quercetin-3-O-rutinoside [20]. Kim et al. reported that neochlorogenic acid, a natural polyphenolic compound found in dried fruits, suppresses COX-2 protein expression on murine microglial BV2 cells [21]. Mandour et al. reported that quercetin-3-O-glucuronide inhibited COX-1 and COX-2 enyzmes with 37.60\% and $60.00 \%$ at $25 \mu \mathrm{g} / \mathrm{ml}$ and quercetin-3-O-galactoside showed COX-1 and COX-2 with $39.20 \%$ and $60.70 \%$ at same concentration [22]. In another study, Comolada et al. reported that quercetin-3-O-rhamnoside showed benefical effects of in vivo model of intestinal inflammation [23]. Ning et al. reported that quercetin3-O-glucuronide showed inhibitory effect against a-glucosidase enzyme [24]. As shown in Table 1, LME inhibited a-glucosidase in a concentration-dependent manner and it had significant inhibitory effect compared to acarbose at 25, 50 and $100 \mu \mathrm{g} / \mathrm{ml}(\mathrm{p}<0.001)$. On the other hand, FME displayed no aglucosidase inhibitory effects at studied concentrations. Suprisingly, a-glucosidase activity increased in the presence of FME at 12.5, 25, 50 and $100 \mu \mathrm{g} / \mathrm{ml}$. On the contrary of our work, Truba et al. reported that aqueous-ethanolic extract of $C$. sanguinea fruit exhibited inhibitory effect against a-glucosidase enzyme and the $\mathrm{IC}_{50}$ value of it was determined as $70.07 \pm 16.62 \mu \mathrm{g} / \mathrm{ml}$ [25]. In this study, the results of in vitro AChE inhibitory potentials of the extracts showed that LME showed higher inhibitory effects that of FME but it had lower inhibitory action than galantamine. To the best of our knowledge, there was not any report on the cholinesterase inhibitory effect of $C$. sanguinea but there are few studies about the same activitiy of genus Cornus so far. Bhakta et al. isolated seven compounds from the fruits of Cornus officinalis, cornuside, 1,2,3-tri$O$-galloyl- $\beta$-D-glucose, 1,2,3,6-tetra- $O$-galloyl- $\beta$-D-glucose, tellimagradin $\mathrm{I}$, tellimagrandin II, and isoterchebin and investigated AChE inhibitory effects of them using Ellman's method [26]. The IC 50 values of cornuside, 1,2,3-tri-O-galloyl- $\beta$-D-glucose, 1,2,3,6-tetra- $O$-galloyl $\beta$-D-glucose, tellimagradin I, tellimagrandin II, and isoterchebin were calculated as $>100 \mu \mathrm{M},>100 \mu \mathrm{M}, 85.64 \pm 0.03 \mu \mathrm{M}, 87.52 \pm 0.32 \mu \mathrm{M}, 11.86 \pm 0.56 \mu \mathrm{M}$, $47.55 \pm 0.54 \mu \mathrm{M}$, respectively. In addition, tellimagradin I, tellimagrandin II, and isoterchebin inhibited AChE via mixed, competitive, and mixed inhibitory type [26]. The tyrosinase inhibitory effects of the both extracts were presented in Figure 3 and LME had higher inhibitory action that of FME but kojic acid showed stronger inhibitory effects than both extracts. These obtained results showed compatibility with other inhibitory activities. An et al. reported the tyrosinase effects of methanol extract of Cornus officinalis fruits on melan-a cells. Their results showed that methanol extract upregulated tyrosinase activitiy on this cell line [27]. DPPH radical scavenging assay is the common technique to evaluate antioxidant effect due to being a cost-effective, fast and sensitive method [28]. The obtained results displayed that both extracts scavenged DPPH radical in a concentration-dependent manner. LME had remarkable radical scavenging action at 50 and $100 \mu \mathrm{g} / \mathrm{ml}$ and it had stronger scavenging effect than FME. Stankovic and Topuzovic reported that $\mathrm{IC}_{50}$ values of DPPH radical scavenging effects of methanol extracts of $C$. sanguinea leaves and fruits collected from Serbia were $19.84 \pm 0.11$ and $358.59 \pm 1.14 \mu \mathrm{g} / \mathrm{ml}$. Their results showed that leaves have higher antioxidant activity when compared to fruits [2]. Yousfbeyk et al. reported that $\mathrm{IC}_{50}$ value of methanol $(1 \% \mathrm{HCl})$ extract from $C$. sanguinea in Iran was found to be $90.43 \mu \mathrm{g} / \mathrm{ml}$ [7]. The results showed that enzyme inhibitory and antioxidant effects depend on the polarity of solvent, plant part, extraction method etc. However, our results were consistent with data given in literature.

\section{CONCLUSION}

In this study, we investigated total phenolic content, COX-1/COX-2, a-glucosidase, AChE, tyrosinase inhibitory and DPPH radical scavenging effects of LME and FME obtained C. sanguinea from Turkey. The total phenolic contents of LME and FME were found to be $191.14 \pm 4.84$ and $31.51 \pm 2.68 \mathrm{mg}$ GAE/g dry weight, respectively. LME had higher total phenolic content than that of FME about six-fold. LME inhibited COX-1 enzyme with $70.71 \pm 1.88 \%$ and $79.38 \pm 0.92 \%$ at 50 and $100 \mu \mathrm{g} / \mathrm{ml}$. It showed significant COX-1 inhibitory effect when compared to diclofenac at 25 and $100 \mu \mathrm{g} / \mathrm{ml}$. LME had higher COX-2 inhibitory effects than that of FME. LME inhibited a-glucosidase in a concentration-dependent manner and it had significant inhibition actions as compared to acarbose. Both extracts showed lower AChE inhibition effects as 
compared to galantamine. In tyrosinase inhibition assay, LME had higher inhibition action than that of FME but kojic acid showed stronger inhibitory effects than both extracts. Both extracts scavenged DPPH radical in a concentration-dependent manner. In addition, LME had stronger scavenging effects that of FME at studied concentrations. These results suggested that LME of $C$. sanguinea have a promising potential for the treatment of several degenerative disorders such as including rheumatoid arthritis, diabetes, Alzheimer's disease, and Parkinson's disease etc but in vivo researchs are needed to support the therapeutic actions.

\section{MATERIALS AND METHODS}

\subsection{Plant material}

C. sanguinea was collected from Çamiçi plateau, Niksar, Tokat $\left(40^{\circ}, 38^{\prime}, 52^{\prime \prime} \mathrm{N}, 36^{\circ}, 50^{\prime}, 55^{\prime \prime} \mathrm{E}\right)$ on 28 Agust 2019. The plant material was collected and identified by Assoc. Prof. Dr. Didem Şöhretoğlu. A voucher specimen was deposited in Herbaryum of Hacettepe University, Faculty of Pharmacy (HUEF 19072).

\subsection{Extraction}

The shade-dried leaves $(3 \mathrm{~g})$ were macerated with $\mathrm{MeOH}(50 \mathrm{ml})$ at room temperature for overnight and then extracted at $40^{\circ} \mathrm{C}$ for $8 \mathrm{~h}$. The same process repeated 3 times, and the extracts were combined. The concentrated $\mathrm{MeOH}$ extract was suspended in $\mathrm{H}_{2} \mathrm{O}$ and lyophilized $(0.38 \mathrm{~g})$. Fruits are kept $-20^{\circ} \mathrm{C}$ then the same extraction procedure was applied to $3 \mathrm{~g}$ fruits. After this procedure, $0.65 \mathrm{~g}$ extract was obtained.

\subsection{Estimation of total phenolic content}

The total phenolic content of LME and FME was determined by using the Folin-Ciocalteu reagent according to method by Kahkönen [29]. The extracts and diluted Folin-Ciocalteu reagent (Sigma-Aldrich, 47641), were placed in each well of a 96 well plate. After then sodium carbonate was added. The mixtures were incubated for $30 \mathrm{~min}$ in the dark. Afterwards, the absorbance was measured at $760 \mathrm{~nm}$. The total phenolic contents of LME and FME were expressed as mg gallic acid equivalents (GAE) per g of dry weight of extract.

\subsection{Biological studies}

\subsubsection{COX-1 and COX-2 inhibition assay}

The COX-1 and COX-2 inhibitory effects of LME and FME were carried out by using spectrophotometric methods [30]. Diclofenac and celecoxib were used positive controls for COX-1 and COX2, methanol (\%1) as blank. COX-1 from sheep (Sigma-Aldrich, C0733) and COX-2 from human (SigmaAldrich, C0858) were treated the extracts $(12.5-100 \mu \mathrm{g} / \mathrm{ml})$ in 96-well plate and incubated for $5 \mathrm{~min}$. After incubation, endpoint assay mix (Tris. $\mathrm{Cl} \mathrm{pH} 8.1(1 \mathrm{mM})$, hemin $(100 \mu \mathrm{M}), \mathrm{N}, \mathrm{N}, \mathrm{N}^{\prime}, \mathrm{N}^{\prime}$-tetramethyl-pphenylenediamine $(17 \mathrm{mM})$, arachidonic acid $(10 \mathrm{mM}))$ (Sigma-Aldrich) was added and reaction mixture was incubated for $15 \mathrm{~min}$. The absorbance was measured at $611 \mathrm{~nm}$ using microplate reader. The COX-1 and COX-2 inhibition (\%) and $\mathrm{IC}_{50}$ values $(\mu \mathrm{g} / \mathrm{ml})$ of samples was determined as follows [Eq. 1]:

$$
\text { Inhibition } \left.(\%)=\left[\left(\left(\mathrm{A}_{\text {control }}\right)-\mathrm{A}_{\text {extract }}\right)\right) / \mathrm{A}_{\text {control }}\right] \times 100
$$

\subsection{2. a-Glucosidase inhibition assay}

The a-glucosidase inhibitory effect was investigated according to our previous study with minor modifications [31]. Acarbose was used as a positive control, whereas methanol (1\%) was used as blank. aGlucosidase from Saccharomyces cerevisiae (Sigma-Aldrich, G5003) was treated with the extracts (12.5-100 $\mu \mathrm{g} / \mathrm{ml}$ ) in 96-well plate and incubated for $10 \mathrm{~min}$. After incubation, $p$-nitrophenyl-a-glucopyranoside (5 $\mathrm{mM}$ ) (Sigma-Aldrich, N1377) was added to reaction mixture and incubated for $15 \mathrm{~min}$ at room temperature. The absorbance was measured at $405 \mathrm{~nm}$ using microplate reader. The a-glucosidase inhibition (\%) and $\mathrm{IC}_{50}$ values $(\mu \mathrm{g} / \mathrm{ml})$ of samples was determined by using equation mentioned above.

\subsubsection{AChE inhibition assay}

The inhibitory properties of the extracts on AChE were determined according to our previous study with minor modifications [32]. Galantamine was used as a positive control, whereas methanol (1\%) was used 
as blank. AChE from Electrophorus electricus (Sigma-Aldrich, C3389) were treated with the extracts (12.5$100 \mu \mathrm{g} / \mathrm{ml})$ in 96-well plate and incubated for $10 \mathrm{~min}$. After incubation, Tris.Cl buffer $\mathrm{pH} 8(50 \mathrm{mM}), 5,5-$ dithio-bis(2-nitrobenzoic)acid (3 mM) (Sigma-Aldrich, D8130) were added to mixtures and incubated for 15 min at room temperature. After incubation, acetylthiocholine iodide (Sigma-Aldrich, A5751) was added as a substrate to start enzymatic reaction. The absorbance was measured at $412 \mathrm{~nm}$ using microplate reader. The $\mathrm{AChE}$ inhibition $(\%)$ and $\mathrm{IC}_{50}$ values $(\mu \mathrm{g} / \mathrm{ml})$ of samples was determined by using equation mentioned above.

\subsubsection{Tyrosinase inhibition assay}

The inhibitory properties of the extracts on tyrosinase were investigated according to our previous study with minor modifications [19]. Kojic acid was used as a positive control and methanol (1\%) was used as blank. Tyrosinase from mushroom (Sigma-Aldrich, T3824) in phosphate buffer $\mathrm{pH} 6.8(100 \mathrm{mM})$ were treated with the extracts $(12.5-100 \mu \mathrm{g} / \mathrm{ml})$ in 96-well plate and incubated for $10 \mathrm{~min}$. Afterwards, 3,4dihydroxy-L-phenylalanine ( $3 \mathrm{mM}$ ) (Sigma-Aldrich, D9628) was added to mixtures and incubated for $15 \mathrm{~min}$ at room temperature. The absorbance was measured at $475 \mathrm{~nm}$ using microplate reader. The tyrosinase inhibition $(\%)$ and $\mathrm{IC}_{50}$ values $(\mu \mathrm{g} / \mathrm{ml})$ of samples was determined by using equation mentioned above.

\subsubsection{2,2-diphenyl-1-picrylhydrazyl (DPPH) radical scavenging assay}

The DPPH radical scavenging effects of the extracts were carried out according to our previous study with slight modification [33]. Gallic acid was used as a positive control and methanol (1\%) was used as blank. DPPH solution $(0.2 \mathrm{mM})$ (Sigma-Aldrich, D9132) was added the extracts $(12.5-100 \mu \mathrm{g} / \mathrm{ml})$ in $96-$ well plate and incubated for $30 \mathrm{~min}$. The absorbance was measured at $517 \mathrm{~nm}$ using microplate reader. The DPPH radical scavenging effects $(\%)$ and $\mathrm{IC}_{50}$ values $(\mu \mathrm{g} / \mathrm{ml})$ of samples were determined by using equation mentioned above.

\subsection{Statistical analysis}

The data were analyzed using GraphPad Prism 5.0 and data were expressed as the mean \pm SD. Statistical analysis was investigated with two-way analysis of variance (ANOVA) followed by Bonferroni tests.

Author contributions: Concept - B.B., D.Ş.; Design - B.B., D.Ş.,; Supervision - D.Ş.; Resources - B.B., D.Ş.; Materials B.B.; Data Collection and/or Processing - B.B., D.Ş.; Analysis and/or Interpretation - B.B., D.Ş.,; Literature Search B.B., D.Ş.,; Writing - B.B.; D.Ş.; Critical Reviews - B.B., D.Ş.

Conflict of interest statement: The authors declared no conflict of interest.

\section{REFERENCES}

[1] David L, Moldovan B, Baldea I, Olteanu D, Bolfa P, Clichici S, Filip GA. Modulatory effects of Cornus sanguinea L. mediated green synthesized silver nanoparticles on oxidative stress, COX-2/NOS2 and NFkB/pNFkB expressions in experimental inflammation in Wistar rats. Mater Sci Eng C. 2020; 110: 110709. [CrossRef]

[2] Stankovic MS, Topuzovic MD. In vitro antioxidant activity of extracts from leaves and fruits of common dogwood (Cornus sanguinea L.). Acta Bot Gallica. 2012; 159(1): 79-83. [CrossRef]

[3] Chamberlain DF. Cornus L. In: Davis PH (Ed.) Flora of Trukey and the East Aegean Islands, Vol IV. Edinburgh University Press, Edinburgh, 1972, pp.539-541.

[4] Popovic Z, Smiljanić M, Kostić M, Nikić P, Janković S. Wild flora and its usage in traditional phytotherapy (Deliblato Sands, Serbia, South East Europe). Indian J Tradit Knowl. 2014; 13: 9-35.

[5] Bulut G. Folk medicinal plants of Silivri (Istanbul, Turkey). Marmara Pharm J. 2011; 15: 25-29. [CrossRef]

[6] Saraç DU, Özkan ZC, Akbulut S. Ethnobotanic features of Rize/Turkey province. Biol Divers Conservat. 2013; 6: 57-66.

[7] Yousfbeyk F, Esmaiili T, Pashna Z, Hozori Z, Ghohari AR, Ostad SN, Amin GR. Antioxidant activity, total phenol and total anthocyanin contents of Cornus sanguinea L subsp australis. (C.A. Mey.) Jáv. J Med Plant. 2014; 13(49): 6974 . 
[8] Popović Z, Bajić-Ljubičić J, Matić R, Bojović S. First evidence and quantification of quercetin derivatives in dogberries (Cornus sanguinea L.). Turk J Biochem. 2017; 42(4): 513-518. [CrossRef]

[9] Oskay M, Sarı D. Antimicrobial screening of some Turkish medicinal plants. Pharm Biol. 2007; 45(3): 176-181. [CrossRef]

[10] Zhang L, Lv J. Sesquiterpenoids from Artemisia argyi and their COXs inhibitory activities. Fitoterapia 2019; 139: 104372. [CrossRef]

[11] Larsen BHV, Soelberg J, Jager AK. COX-1 inhibitory effect of medicinal plants of Ghana. S Afr J Bot. 2015; 99: 129_ 131. [CrossRef]

[12] Tamgewagh UU, Kandhare AD, Honmore VS, Kadam PP, Khedkar VM, Bodhankar SL, Rojatkar SR. Antiinflammatory and antioxidant potential of guaianolide isolated from Cyathocline purpurea: Role of COX-2 inhibition. Int Immunopharmacol. 2017; 52: 110-118. [CrossRef]

[13] Ni M, Hu X, Gong D, Zhang G. Inhibitory mechanism of vitexin on a-glucosidase and its synergy with acarbose. Food Hydrocoll. 2020; 105: 105824. [CrossRef]

[14] Zhao L, Wen L, Lu Q, Liu R. Interaction mechanism between a-glucosidase and a-type trimer procyanidin revealed by integrated spectroscopic analysis techniques. Int J Biol Macromol. 2020; 143: 173-180. [CrossRef]

[15] Ragab HM, Teleb M, Haidar HR, Gouda N. Chlorinated tacrine analogs: Design, synthesis and biological evaluation of their anti-cholinesterase activity as potential treatment for Alzheimer's disease. Bioorg Chem. 2019; 86: 557-568. [CrossRef]

[16] Imran M, Irfan A, Ibrahim M, Assiri MA, Khalid N, Ullah S, Al-Sehem AG. Carbonic anhydrase and cholinesterase inhibitory activities of isolated flavonoids from Oxalis corniculata L. and their first-principles investigations. Ind Crop Prod. 2020; 148: 112285. [CrossRef]

[17] Bilska A, Kobus-Cisowska J, Kmiecik D, Danyluk B, Kowalski R, Szymanowska D, Gramza-Michlowska A, Szczepaniak O. Cholinesterase inhibitory activity, antioxidative potential and microbial stability of innovative liver pâté fortified with rosemary extract (Rosmarinus officinalis). Electron J Biotechn. 2019; 40: 22-29. [CrossRef]

[18] Sari S, Barut B, Özel A, Şöhretoğlu D. Tyrosinase inhibitory effects of Vinca major and its secondary metabolites: Enzyme kinetics and in silico inhibition model of the metabolites validated by pharmacophore modeling. Bioorg Chem. 2019; 92: 103259. [CrossRef]

[19] Şöhretoğlu D, Sari S, Barut B, Özel A. Tyrosinase inhibition by some flavonoids: Inhibitory activity, mechanism by in vitro and in silico studies. Bioorg Chem. 2018; 81: 168-174. [CrossRef]

[20] Popovic Z, Matic R, Bajic-Ljubicic J, Tesevic V, Bojovic S. Geographic variability of selected phenolic compounds in fresh berries of two Cornus species. Trees 2018; 32: 203-214. [CrossRef]

[21] Kim M, Choi S, Lee P, Hur J. Neochlorogenic acid inhibits lipopolysaccharide-induced activation and proinflammatory responses in BV2 microglial cells. Neurochem Res. 2015; 40: 1792-1798. [CrossRef]

[22] Mandour Y, Handoussa H, Swilam N, Hanafi R, Mahran L. Structural docking studies of COX-II inhibitory activity for metabolites derived from Corchorus olitorius and Vitis vinifera. Int J Food Prop. 2016; 19: 2377-2384. [CrossRef]

[23] Comolada M, Camuesco D, Sierra S, Ballester I, Xaus J, Galvez, Zarzuelo A. In vivo quercitrin anti- inflammatory effect involves release of quercetin, which inhibits inflammation through down- regulation of the NF- $\kappa B$ pathway. Euro J Immun. 2005; 35: 584-592. [CrossRef]

[24] Ning Z, Zhai L, Huang T, Peng J, Hu D, Xiao H, Wen B, Lin C, Zhao L, Bian Z, Identification of a-glucosidase inhibitors from cyclocarya paliurus tea leaves using UF-UPLC-Q/TOF-MS/MS and molecular docking. Food Funct. 2019; 10: 1893-1902. [CrossRef]

[25] Truba J, Stanislawska I, Walasek M, Wieczorkowska W, Wolinski K, Buchholz T, Melzig MF, Czerwinska ME. Inhibition of digestive enzymes and antioxidant activity of extracts from fruits of Cornus alba, Cornus sanguinea subsp. hungarica and Cornus florida-A comparative study. Plants 2020; 9: 122. [CrossRef]

[26] Bhakta HK, Park CH, Yokozawa T, Tanaka T, Jung HA, Choi JS. Potential anti-cholinesterase and $\beta$-site amyloid precursor protein cleaving enzyme 1 inhibitory activities of cornuside and gallotannins from Cornus officinalis fruits. Arch Pharm Res. 2017; 40: 836-853. [CrossRef]

[27] An YA, Hwang JY, Lee JS, Kim YC. Cornus officinalis methanol extract upregulates melanogenesis in melan-a cells. Toxicol Res. 2015; 31(2): 165-172. [CrossRef] 
[28] Kandia S, Linton Charles A. Statistical comparative study between the conventional DPPH\% spectrophotometric and dropping $\mathrm{DPPH} \%$ analytical method without spectrophotometer: Evaluation for the advancement of antioxidant activity analysis. Food Chem. 2019; 287: 338-345. [CrossRef]

[29] Kahkönen MP, Hopia AI, Vuorela HJ, Rauha J, Pihlaja K, Kujala TS, Heinonen M. Antioxidant activity of plant extracts containing phenolic compounds. J Agric Food Chem. 1999; 47(10): 3954-3962. [CrossRef]

[30] de Oliveira ADT, de Miranda MDS, Jacob ITT, da Cruz Amorim CA, de Moura RO, da Silva SAS, Soares MBP, de Almeida SMV, de Lima Souza TRC, de Oliveira JF, da Silva TG, de Melo, CRL, Moreira DRM, de Lima MC. Synthesis, in vitro and in vivo biological evaluation, COX-1/2 inhibition and molecular docking study of indole-Nacylhydrazone derivatives. Bioorg Med Chem. 2018; 26: 5388-5396. [CrossRef]

[31] Barut B, Barut EN, Engin S, Özel A, Sezen FS, Investigation of the antioxidant, a-glucosidase inhibitory, antiinflammatory, and DNA protective properties of Vaccinium arctostaphylos L. Turk J Pharm Sci. 2019; 16: 175-183. [CrossRef]

[32] Barut EN, Barut B, Engin S, Yıldırım S, Yaşar A, Turkis S, Özel A, Sezen FS. Antioxidant capacity, antiacetylcholinesterase activity and inhibitory effect on lipid peroxidation in mice brain homogenate of Achillea millefolium. Turk J Biochem. 2017; 42: 493-502. [CrossRef]

[33] Sellitepe HE, Doğan İS, Eroğlu G, Barut B, Özel A. Synthesis, characterization and investigation of cholinesterase enzyme inhibition and antioxidant activities of some 4-aryl-1,4-dihydropyridine derivatives. J Res Pharm. 2019; 23(4): 608-616. [CrossRef]

This is an open access article which is publicly available on our journal's website under Institutional Repository at http://dspace.marmara.edu.tr. 